\title{
Effect of arsenate on germination and early development parameters of three forage leguminous plants
}

\author{
Efeito do arsenato nos parâmetros de germinação e desenvolvimento inicial de três plantas \\ leguminosas forrageiras
}

\author{
Cristina V. Alvarez Gonçalvez ${ }^{1,2}$, Magali Rodriguez ${ }^{1}$, Alicia Fernández Cirelli ${ }^{1,2}$, Alejo Leopoldo Pérez \\ Carrera $^{1,22_{\star}}$
}

${ }^{1}$ Universidad de Buenos Aires, Facultad de Ciencias Veterinarias, Buenos Aires, Argentina.

${ }^{2}$ Instituto de Investigaciones en Producción Animal (INPA), Buenos Aires, Argentina. *Author for correspondence: alpc@fvet.uba.ar

Submission: 03/08/2019 / Acceptance: 06/03/2020

\begin{abstract}
The Chacopampean plain is one of the most arsenic affected areas in Argentina, especially in groundwater, used both for animal drinking and forage irrigation. The main objective of this study was to determine the effect of arsenic (As) present in irrigation water on the germination parameters of red clover (Trifolium pratense L.), white clover (Trifolium repens L.), and alfalfa (Medicago sativa L.) seeds exposed to different concentrations of $\mathrm{As}(\mathrm{V})$. The germination and viability parameters of seeds from the three species were not affected by elevated concentrations of As. However, As significantly reduced the radicle and hypocotyl lengths of the three forage specimens. The inhibition level of the plants increased with the increase in the concentration of As. Regarding to hypocotyl length/radicle length ratio, the results evidenced that both the hypocotyl and radicle of clover species are affected in the same degree, while alfalfa radicles seemed more affected than hypocotyls at higher concentrations of As. Our results showed that irrigation with solutions containing As affect seedling growth parameters differently in the three species, and the effect of As is mostly evidenced when in high concentrations.
\end{abstract}

KEYWORDS: arsenic, forage, seeds.

\section{RESUMO}

A planície de Chacopampeana é uma das áreas mais afetadas pelo arsênico na Argentina, principalmente em águas subterrâneas, usada tanto para água potável animal quanto para irrigação forrageira. O principal objetivo deste estudo é determinar o efeito do arsênio (As) presente na água de irrigação sobre os parâmetros de germinação de sementes forrageiras: trevo vermelho (Trifolium pratense L.), trevo branco (Trifolium repens L.) e alfafa (Medicago sativa L.) expostos a diferentes concentrações de As (V). Verificouse que os parâmetros de germinação e viabilidade das sementes das três espécies não foram afetados pelas concentrações elevadas de As. No entanto, reduziu significativamente o comprimento da radícula e o comprimento do hipocótilo das três mudas de forragem, e seu nível de inibição é maior com o aumento da concentração de As. Quanto à relação comprimento de hipocótilo/comprimento da radícula, os resultados evidenciaram que nas espécies de trevo tanto o hipocótilo quanto a radícula são afetados no mesmo grau, enquanto as radículas de alfafa pareceram mais afetadas do que os hipocótilos em concentrações maiores de As. Nossos resultados mostraram que a irrigação com soluções contém Afetar os parâmetros de crescimento de plântulas de maneira diferente nas três espécies, e foi demonstrado que o efeito do As é principalmente evidenciado em altas concentrações.

PALAVRAS-CHAVE: arsênico, forragem, sementes.

Arsenic (As) is an element non-essential to living organisms, that is naturally present on the environment, especially in groundwater. It is present in both organic and inorganic forms, but the last are the main chemical species in water and soil (CHEN et al. 2007). The most common oxidation states of As are +5 , +3 , and -3. Inorganic As species includes arsenite As (III), which is most toxic and mobile than arsenate As (V) (CHEN et al. 2016). Among the organic forms, the most common species are methylarsinate, dimethylarsinate, trimethylarsine oxide, arsenobetaine, arsenocholine, and arsenosugars. Arsenic is known as a carcinogenic element (WAALKES et al. 2004, BHATTACHARJEE et al. 2013, COHEN et al. 2013, 
BROCATO et al. 2015). Most of the organic species are less toxic than the inorganic species (BUNDSCHUH et al. 2008, CHEN et al. 2016, Ll et al. 2016).

High As levels in groundwater have been registered in several countries worldwide. In Latin America, the most affected countries are Argentina, Bolivia, Peru, Chile, and Mexico (BECH et al. 1997, BUNDSCHUH et al. 2012, ALARCÓN-HERRERA et al. 2013, ALONSO et al. 2014). In Argentina, the Chacopampean plain is one of the most important areas for agriculture. In this zone, groundwater As originates from aquifer rocks (NICOLLI et al. 1989, SMEDLEY \& KINNIBURGH 2002).

Plants may be exposed to As through both irrigation water and soil. Arsenic is involved in several chemical processes within plants, including in reduced, detoxified, and sequestered forms. It mimics phosphorous, binds sulfhydryl groups, and causes oxidative stress (ISLAM et al. 2015, HUANG et al. 2012). As (III) and As (V) flow in plants through different pathways. As (III) enters plant cells via aquaporins (MA et al. 2008, ZHAO et al. 2009). The aquaporin transporter AtNiP1-2 is highly expressed especially in seeds (LI et al. 2016). As (V) is taken up via phosphate transporters, using a co-transport mechanism with two protons (ESTEBAN et al. 2003, ZHAO et al. 2009). Inside the cell, arsenate is reduced to arsenite by arsenate reductase, which consumes reduced glutathione (ZHAO et al. 2010, ZHU et al. 2014). As (III) tends to be complexed due to its high affinity for protein SH groups. It binds to phytochelatins, glutathione oligomers produced by the enzyme phytochelatin synthase and is stored into vacuoles in root cells (BATISTA et al. 2014). Also, part of this arsenite is translocated to other plant tissues (ZHAO et al. 2009, PÉREZ-CARRERA \& FERNÁNDEZ-CIRELLI 2014). Despite this arsenic resistance, uptake, translocation to different parts of the plant, and bioaccumulation rate, it has not yet been well studied (LI et al. 2016). Several studies show that these phenomena depend on several factors, such as soil characteristics, microbiological activity, other ions present in the water and soil, plant species, genetic background, and others (HARTLEY \& LEPP 2008, SMITH et al. 2010, RAHMAN \& HASEGAWA 2011, RAl et al. 2011, FU et al. 2011, MARQUEZ-GARCIA et al. 2012, AMARAL et al. 2013, IRIEL et al. 2015). Arsenic levels in soil or in irrigation water can affect forage growth and its nutritional characteristics and can represent a risk to foraging cattle (PÉREZ-CARRERA \& FERNÁNDEZ-CIRELLI 2014).

Among the deleterious effects of As on plants, we highlight a decrease in phosphorus uptake since both elements compete for phosphate transport systems. For instance, arsenate acts like P (FARNESE et al. 2014). LIU et al. (2008) showed that As also interferes with the metabolism of other elements, such as calcium $(\mathrm{Ca})$, magnesium $(\mathrm{Mg})$, potassium $(\mathrm{K})$, manganese $(\mathrm{Mg})$, and zinc $(\mathrm{Zn})$. In several plant species, many effects occurred on growth, biomass production, number of leaves, root length, plant height, diverse morphological changes, disorganization of photosynthesis, generation of reactive oxygen species, and declination on germination rate (CARBONELL-BARRACHINA et al. 1998, MITEVA 2002, SRIVASTAVA et al. 2005, AHMED et al. 2006, SHAIBUR et al. 2008, SMITH et al. 2010, PÉREZ-CARRERA \& FERNÁNDEZ-CIRELLI 2014). Despite this, MA (2001) reported that in low concentrations, As may stimulate the growth of many plants. However, the mechanism is still unclear.

It has been proposed that the effect of As in legumes can depend on the interaction between nodule bacteria and plant (CHEN et al. 2007, XU et al. 2008). MACUR et al. (2001) has reported that rhizobial bacteria can grow in soils with high As levels. However, As also causes the reduction in nodule numbers due to a declination in plant infection (PAJUELO et al. 2008). This process depends on the specie of nodule bacteria (CHRISTOPHERSEN et al. 2012). Due to these characteristics, legumes with As resistant nodules, have been proposed for remediation strategies on As contaminated areas (CARRASCO et al. 2005, KHAN et al. 2009). The effect of As on plants could depend of mycorrhizal fungus, because As speciation in plants change with the presence of fungus, increasing the percentage of As (III) in plant tissues (LOMAX et al. 2012, ZHANG et al. 2015). However, the effect of arsenic in forages hasn't been well studied.

In the Chacopampean plain in Argentina, the clover (Trifolium pratense L.), white clover (Trifolium repens L.), and alfalfa (Medicago sativa L.) are the three leguminous species most commonly used as forage for cattle due to their high protein content. Therefore, the aim of this study was to determine the effect of As present in irrigation water on the germination parameters of three forage leguminous plant seeds exposed to different concentrations of As $(\mathrm{V})$.

The seeds used in this work (Trifolium repens L., Trifolium pratense L. and Medicago sativa L.) were supplied by a national provider of commercial seeds. Their viability was confirmed through a germination test before beginning the experiments. Seeds showed a $90 \%$ of germination by the fifth day. Ideal stocking Rev. Ciênc. Agrovet., Lages, SC, Brasil (ISSN 2238-1171) 237 
conditions (temperature and relative humidity) were guaranteed in all experiments. Sterile plastic Petri dishes and $80 \mathrm{~g} / \mathrm{m}^{2}$ filter paper, $250 \mu \mathrm{m}$ thick, with pores of $14 \mu \mathrm{m}$ and a permeability of $14 \mathrm{l} / \mathrm{s} / \mathrm{m}^{2}$ (measured by method DIN 53887) were used. The arsenic exposure experiment took place under controlled conditions, in darkness, and at a constant temperature of $22{ }^{\circ} \mathrm{C} \pm 2{ }^{\circ} \mathrm{C}$. A modified version of an international protocol was used - EPA 600/3 (GREENE JC et al. 1988). Sodium arsenate heptahydrate $\left(\mathrm{NaHAsO}_{4} \cdot 7 \mathrm{H}_{2} \mathrm{O}\right)$ from Biopack (CAS\#10048-95-0) was used to prepare the As solutions at the concentrations of 50,100,500,1000, and $5000 \mu \mathrm{g} / \mathrm{L}$. Potassium dichromate $2 \% \mathrm{~m} / \mathrm{v}$ was used as positive control. The selected concentrations of As used in this experiment resemble natural concentrations of As in irrigation water in Argentina (NICOLLI et al. 1989, FARIAS 2003, PÉREZ-CARRERA \& FERNÁNDEZ-CIRELLI 2013).

Groups of 25 seeds were placed in the Petri dishes and soaked with two $\mathrm{ml}$ of each solution. A positive control of potassium dichromate $0.2 \%$ and a negative control of distilled water were used. All treatments were conducted using three replicates. The Petri dishes were kept in darkness and under controlled humidity and temperature conditions for five days. All the germinated seeds were counted and the radicle and hypocotyl lengths were measured. All seedlings with a radicle longer than $2 \mathrm{~mm}$ were considered germinated. The seedlings were photographed with a high-resolution camera and their radicle and hypocotyl length were measured by digital software.

The experiments were conducted using the completely randomized design. All the results were analyzed by a blind system. Analysis of variance (ANOVA) was used to determine the statistical significance of the differences between the means of the treatments in all experiments. For the germination analysis, arc sin transformation was used before ANOVA (ZAR et al. 1996).

The No Observable Adverse Effect Concentration (NOAEC) values for seed germination and hypocotyl and root elongation were determined using Dunnett's procedure for multiple comparisons. ANOVAs and other statistical parameters were calculated using InfoStat Student Version. The $\mathrm{EC}_{50}$ for seedling growth was determined by expressing each treatment as a proportion of the control seedling growth (HAMILTON et al. 1977, USEPA 1999).

Basal germination rates were 69,80 , and $88 \%$ for alfalfa, white clover, and red clover, respectively. The effect of arsenic on seed germination was analyzed for the different As solutions. For the three species, there was no significant variation on germination percentage between treatments $(p>0.05)$. Despite this, there was a decrease in the tendency for seed germination at high concentrations of As (Figure 1).

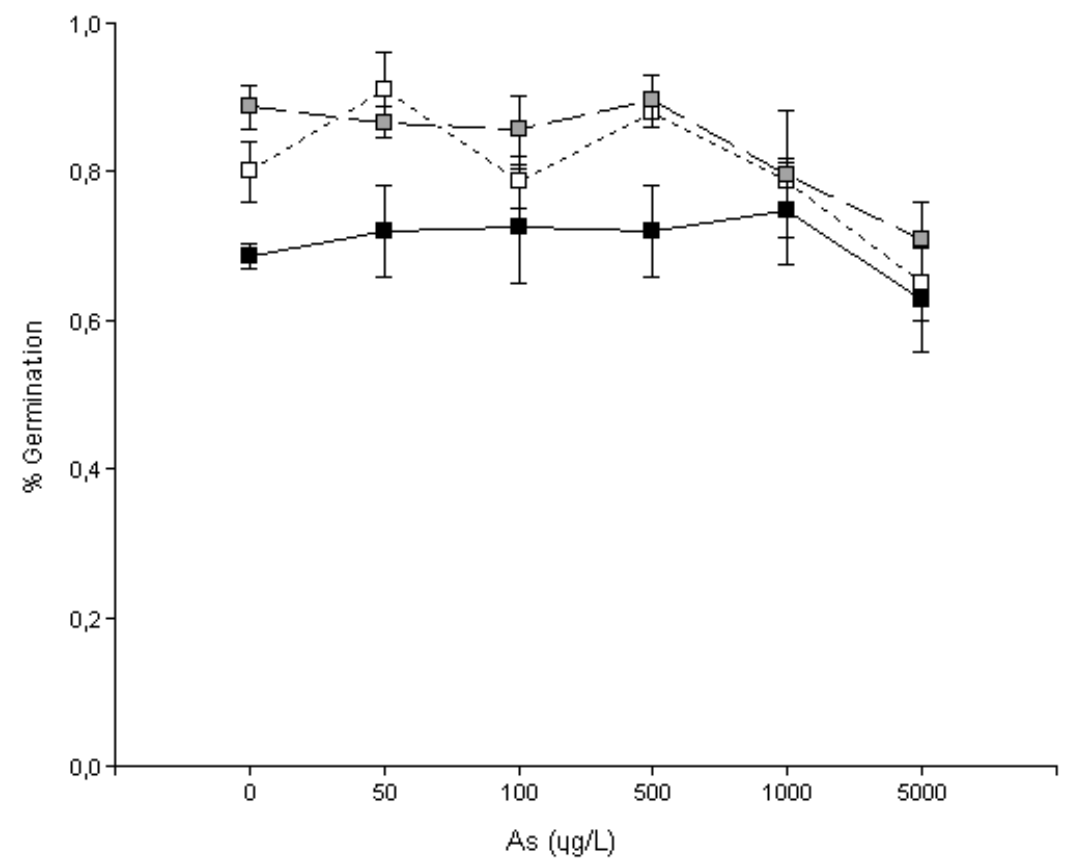

Figure 1. Normalized percentage of germination for the three legume species: white clover (white), red clover (grey), and alfalfa (dark). There were no significant differences $(p<0.05)$ between treatments for each species. Infostat. 
Toxicity to forage can be evidenced by the decrease on hypocotyl and radicle lengths. A significant difference among the treatments was observed, showing a decreasing tendency in both hypocotyl and radicle lengths when As levels increased. The effect was higher in both alfalfa and red clover when compared to white clover. The analysis of the hypocotyl elongation changes in alfalfa showed a significant difference when compared to the control $(p<0.05)$ at $500 \mu \mathrm{g} / \mathrm{L}$ or higher concentrations of As. In contrast, red clover appears to be more sensitive, with significant differences $(p<0.05)$ in hypocotyl elongation appearing at concentrations equal or above $100 \mu \mathrm{g} / \mathrm{L}$. In the case of white clover, a significant reduction $(p<0.05)$ was observed from 1000 $\mu g / L$ (Figure 2).

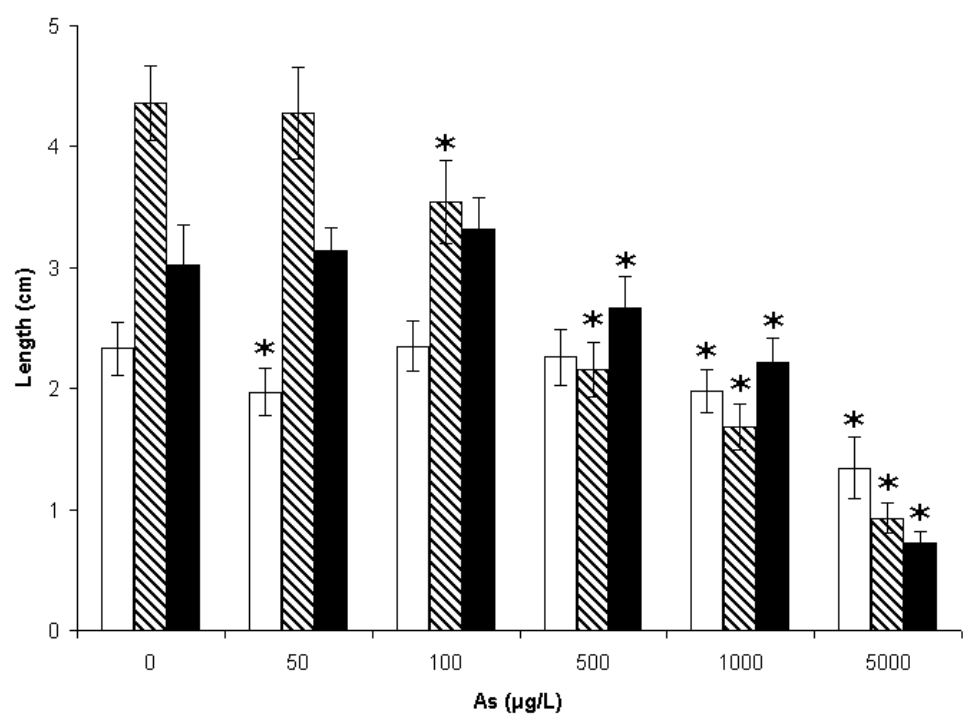

Figure 2. Hypocotyl length for the three legume species: white clover (white), red clover (lined), and alfalfa (dark) for different treatments. The bars show intervals of confidence. Asterisks denotes significant differences $(p<0.05)$ between the treatments and the contro.

Regarding the effect on radical elongation, alfalfa showed a significant difference $(p<0.05)$ from the control at $1000 \mu \mathrm{g} / \mathrm{L}$. Red clover also appears to be more sensitive, showing significant differences $(p<0.05)$ in radicle elongation at concentrations equal or above $100 \mu \mathrm{g} / \mathrm{L}$. In the case of white clover, a significant reduction in radicle length $(p<0.05)$ was observed with As concentration higher than $1000 \mu \mathrm{g} / \mathrm{L}$ (Figure 3).

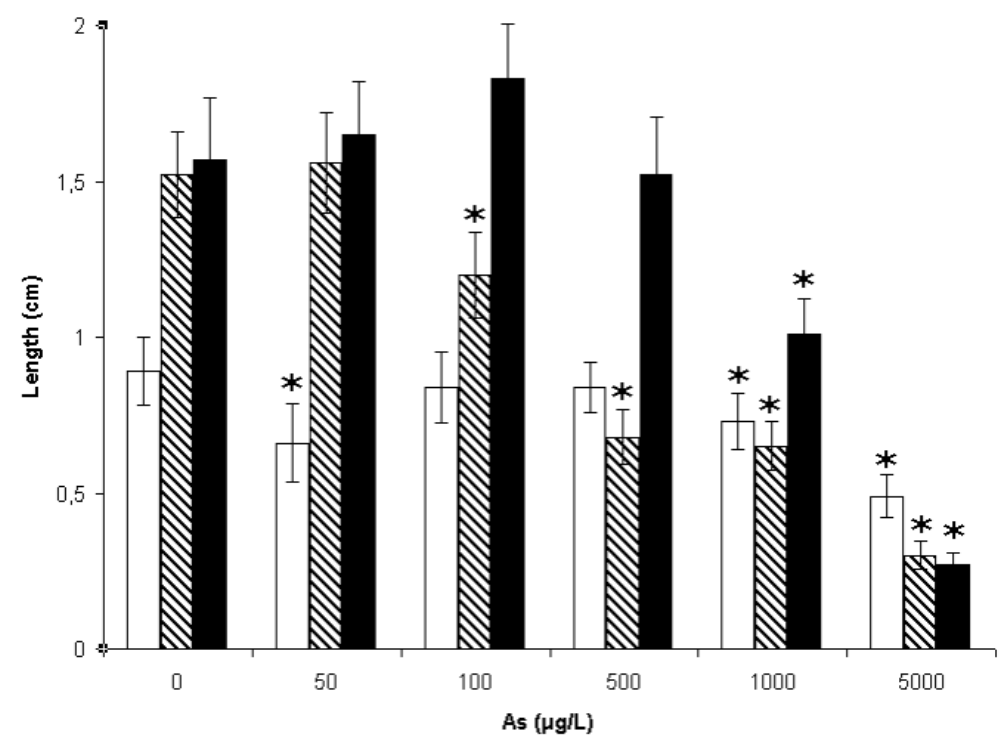

Figure 3. Radicle length for the three legume species: white clover (white), red clover (lined), and alfalfa (dark) for different treatments. The bars show intervals of confidence. Asterisks denote significant differences $(p<0.05)$ between the treatments and the control. 
The hypocotyl length/radicle length ratio $(H L / R L)$ was measured for the three studied forage species as another toxicity indicator. There were no significant differences between treatments on both clover species. Alfalfa showed a tendency to increase the $\mathrm{HL} / \mathrm{RL}$ ratio with the increase in As concentration. This legume showed a significant difference $(p<0.05)$ to the control at $1000 \mu \mathrm{g} / \mathrm{L}$ (Figure 4).

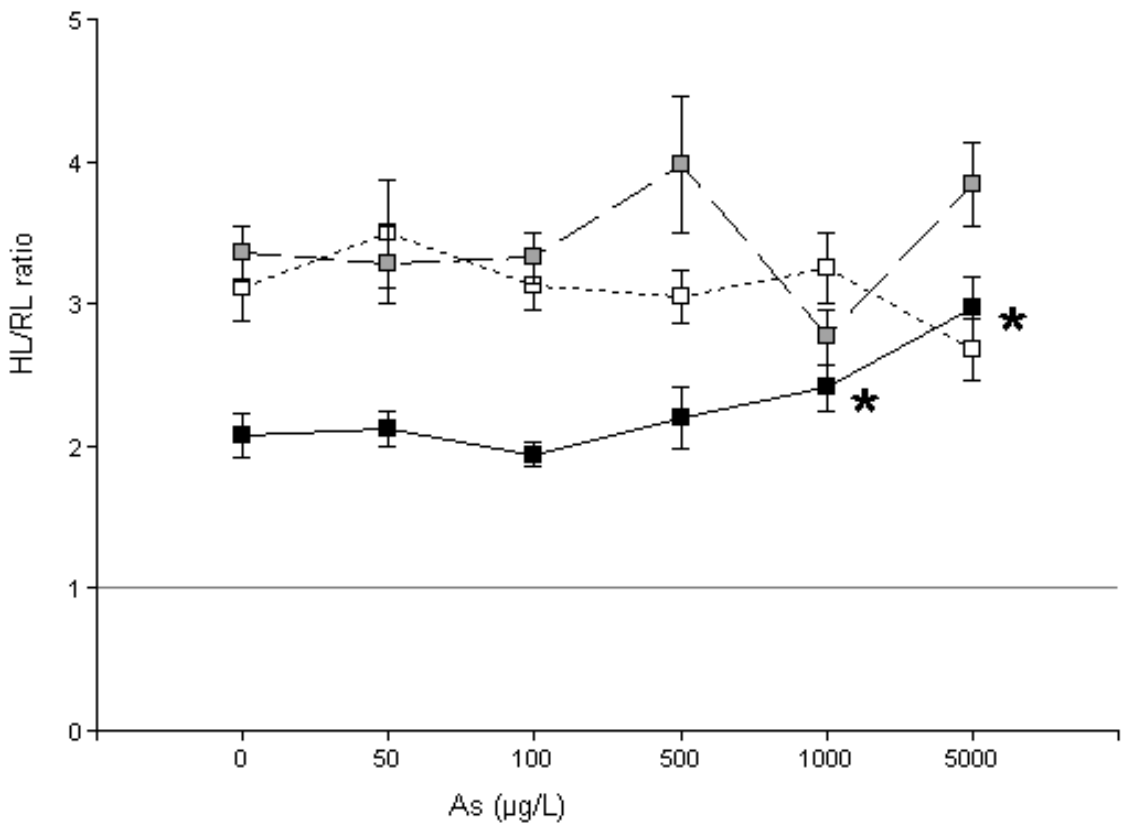

Figure 4. Hypocotyl length $(H L) / r a d i c l e ~ l e n g t h ~(R L)$ ratio for the three legume species: white clover (white), red clover (gray), and alfalfa (dark) for different treatments. The bars show intervals of confidence. Asterisks denote significant differences $(p<0.05)$ between the treatments and the control.

No observable adverse effect concentration (NOAEC) and 50\% and 10\% effect concentration $\left(\mathrm{EC}_{50}\right.$ and $E C_{10}$ ) were calculated for the three species. $\mathrm{EC}_{50}, \mathrm{EC}_{10}$, and $\mathrm{R}^{2}$, for root and shoot growth and the percentage of germination were calculated by expressing each treatment as the inhibition percentage in relation to the control treatment. The toxic effects of As on germination and growth parameters are summarized in Table1.

Table 1. NOAEC, $\mathrm{EC}_{50}$, and $\mathrm{EC}_{10}$ values for germination and growth parameters of seeds exposed to As (V) for 5 days, and $R^{2}$ value of the regression line.

\begin{tabular}{llcccc}
\hline Parameter & \multicolumn{1}{c}{ Specie } & $\begin{array}{c}\mathrm{EC}_{10} \\
\mathrm{mg} / \mathrm{L}\end{array}$ & $\begin{array}{c}\mathrm{EC}_{50} \\
\mathrm{mg} / \mathrm{L}\end{array}$ & $\begin{array}{c}\mathrm{NOAEC} \\
\mathrm{mg} / \mathrm{L}\end{array}$ & $\mathrm{R}^{2}$ \\
\hline Germination percentage & M. sativa L. & --- & --- & $>5$ & --- \\
& T. repens L. & --- & --- & $>5$ & -- \\
& T. pratense L. & -- & -- & $>5$ & -- \\
\% Inhibition Elongation Hypocotyl & & & & & \\
& & & & \\
& T. sativa L. & 0.50 & 2.05 & 0.10 & 0.995 \\
& T. pratense L. & 0.75 & $>5$ & 0.50 & 0.999 \\
\% Inhibition Elongation Radicle & & 0.06 & 0.60 & 0.05 & 0.973 \\
& & & & & \\
& M. sativa L. & 0.38 & 1.75 & 0.50 & 0.948 \\
& T. repens L. & 2.80 & $>5$ & 0.50 & 0.999 \\
& T. pratense L. & 0.07 & 0.58 & 0.05 & 0.969 \\
\hline
\end{tabular}

Arsenic accumulation and toxic effect were reported for different plants species, such as sorghum, fern, grass, and rice (SRIVASTAVA et al. 2005, SHAIBUR et al. 2008, SHRI et al. 2009, SMITH et al. 2010). Studies conducted with alfalfa in our laboratory (PÉREZ-CARRERA \& FERNÁNDEZ-CIRELLI 2014) showed that the increase in the soil concentration of As also increased As concentration in leaves, stems, and roots, demonstrating the As transference in alfalfa. The accumulation of As in the roots was higher than in other parts of the plant (stem and leaves). Similar results were observed by MASCHER et al. (2002) in red clover Rev. Ciênc. Agrovet., Lages, SC, Brasil (ISSN 2238-1171) 
plants, who found that As levels in the shoot tissues increased when arsenate concentration in the soil increases. They also found that there is a significant reduction of shoot growth at high arsenate levels, concluding that As toxicity was superior in shoots than in roots. These results are comparable to those obtained in the present study. Regarding the increase in plant growth at low concentrations of arsenate, similar results were reported by MASCHER et al. (2002) and IRIEL et al. (2015).

The reduction on the percentage of germination was documented for several plant species (TALUKDAR 2011, UPADHYAYA et al. 2014). VAZQUEZ ALDANA et al. (2013) reported an adverse effect on the germination of Festuca rubra seeds exposed to As that was significant only when its concentration was $>12$ $\mathrm{mg} / \mathrm{L}$, a value more elevated than the As levels used in this experience. Nevertheless, our results suggest that seeds can germinate in a wide range of As concentrations present in irrigation water. Furthermore, As has shown deleterious effects on other germination parameters. LUAN et al. (2008) showed that As has an inhibitory effect on soybean growth parameters. The same effect was reported by YOON et al. (2015) for other plant species. Toxic effects of As on germination and seedling growth of several plant species used as animal feed are presented in Table 2.

Table 2. $\mathrm{EC}_{50}$ value for growth parameters of seeds exposed to $\mathrm{As}(\mathrm{V})$ for 5 days (units: soil $\mathrm{mg} / \mathrm{kg}$ and water $\mu g / L)$.

\begin{tabular}{|c|c|c|c|c|}
\hline Specie & Parameter & Via & EC50 & Reference \\
\hline \multirow[t]{2}{*}{ Triticum aestivum L. } & Germination percentage & Soil & $>500$ & \multirow[t]{2}{*}{ YOON et al. 2015} \\
\hline & Seedling growth & Soil & $334-432$ & \\
\hline \multirow[t]{2}{*}{ Sorghum bicolor $\mathrm{L}$. } & Germination percentage & Soil & $>500$ & \multirow[t]{2}{*}{ YOON et al. 2015} \\
\hline & Seedling growth & Soil & $>500$ & \\
\hline \multirow[t]{2}{*}{ Hordeum vulgare $\mathrm{L}$. } & Germination percentage & Soil & $>500$ & \multirow[t]{2}{*}{ YOON et al. 2015} \\
\hline & Seedling growth & Soil & $>500$ & \\
\hline \multirow[t]{3}{*}{ Medicago sativa L. } & Germination percentage & Water & $>5000$ & This study \\
\hline & Radicle elongation inhibition & Water & 1757 & This study \\
\hline & Hypocotyl elongation inhibition & Water & 2050 & This study \\
\hline \multirow[t]{3}{*}{ Trifolium repens $\mathrm{L}$. } & Germination percentage & Water & $>5000$ & This study \\
\hline & Radicle elongation inhibition & Water & $>5000$ & This study \\
\hline & Hypocotyl elongation inhibition & Water & $>5000$ & This study \\
\hline \multirow[t]{3}{*}{ Trifolium pratense L. } & Germination percentage & Water & $>5000$ & This study \\
\hline & Radicle elongation inhibition & Water & 581 & This study \\
\hline & Hypocotyl elongation inhibition & Water & 605 & This study \\
\hline \multirow[t]{2}{*}{ Glycine max $\mathrm{L}$. } & Root growth & Soil & 195 & LUAN et al. 2008 \\
\hline & Shoot growth & Soil & 299 & LUAN et al. 2008 \\
\hline
\end{tabular}

Other authors also report similar results in other forage species. A study regarding the effects on seed germination and seedling growth of Medicago sativa L., Vicia villosa, and Cajanus cajan L. reported that As levels over $5 \mathrm{mg} \mathrm{kg}$ show deleterious effects on germination and seedling growth for all tree species (MA et al. 2009). MARQUEZ et al. (2007) reported that crimson clover (Trifolium incarnatum L.) exposed to As had an inhibitory effect on the germination and growth.

Both genetic and environmental factors affect seed germination and early seedling growth. Different plant species have developed a variety of mechanisms to adapt to adverse conditions, becoming more or less susceptible to certain substances or environmental conditions (IBRAHIM 2016). Many researchers have evaluated the seed germination process regarding several stress factors (LARA-NUÑEZ et al. 2015, IBRAHIM 2016, CHAMORRO et al. 2016). The response of legumes to As-induced toxicity was investigated in some forage species (MASCHER et al. 2002, DONG et al. 2008, LA FUENTE et al. 2010, PEREZ-CARRERA \& FERNÁNDEZ-CIRELLI 2014). However, the studies concerning the impact of As on germination and early 
plants development are scarce (LI et al. 2007). Regarding the obtained results, even if the effect on seedling growth was significant, a direct effect on the percentage of germination was not observed. This fact could suggest that there is a different response of the plant embryo to As exposure before and after seed germination. This was studied by LI et al. (2005) who reported that the isolated embryos of the plants studied were much more sensitive than intact seeds to the exposure to heavy metals, and in fact, the seeds could germinate in the presence of high concentrations of metals, although growth was inhibited once germination began and the seed coat was broken. As presented by other authors (LI et al. 2005, SEREGIN \& KOZHEVNIKOVA 2005), our study supports the idea that the effect of As on forage legumes can depend on the seed coat structure of each plant species.

In the present study, we analyzed the impact of exposure to As on the early development of forage seeds to improve feed production and provide information for management practices to protect livestock from As toxicity. This investigation showed that seed germination and viability were not affected by high concentrations of As $(\mathrm{V})$. However, As significantly reduced the radicle and hypocotyl lengths of the three forage specimens studied, and their inhibition level increased with the increase of As concentration in irrigation water. Regarding to hypocotyl length/radicle length ratio, the results demonstrated that, in clover species, both hypocotyl and radicle are affected in the same degree, while alfalfa radicles seemed more affected than hypocotyls at As concentrations higher than $1000 \mu \mathrm{g} / \mathrm{L}$. The NOAEC, $\mathrm{EC}_{50}$, and $\mathrm{EC}_{10}$ values are dissimilar between species. This emphasizes the need to evaluate the effect of arsenic on each forage species.

In this context, the present study provides information on the impact of As on forage germination and development. Our results showed that As affect seedling growth parameters in the three species studied, and also suggest that the effect of As on forage legume seeds can depend on the structure and integrity of the seed coat. It was also observed that the impact of As on these plants is mostly evidenced at high As concentrations. Further studies are in progress to understand As uptake, translocation, and effects on forage plants, as well as their impact on livestock health and production and the mechanisms through which As affect germination and seedling growth to clarify the impact of As on agriculture ecosystems.

\section{ACKNOWLEDGEMENTS}

This work was supported by the University of Buenos Aires and CONICET (National Research Council).

\section{REFERENCES}

AHMED FRS et al. 2006. Influences of arbuscular fungus Glomus mosseae on growth and nutrition of lentil irrigated with arsenic contaminated water. Plant and soil 283: 33-41.

ALARCÓN-HERRERA MT et al. 2013. Co-occurrence of arsenic and fluoride in groundwater of semi-arid regions in Latin America: Genesis, mobility and remediation. Journal of Hazardous Materials 262: 960-969.

ALONSO DL et al. 2014. Environmental occurrence of arsenic in Colombia: A review. Environmental Pollution 186: 272281.

AMARAL CD et al. 2013. Sample preparation for arsenic speciation in terrestrial plants - a review. Talanta 15: 291-299.

BATISTA BL et al. 2014. Identification and quantification of phytochelatins in roots of rice to long-term exposure: evidence of individual role on arsenic accumulation and translocation. Journal of Experimental Botany 65: 1467-1469.

$\mathrm{BECH} J$ et al. 1997. Arsenic and heavy metal contamination of soil and vegetation around a copper mine in Northern Peru. Science of The Total Environment 203: 83-91.

BHATTACHARJEE $P$ et al. 2013. Role of genomic instability in arsenic-induced carcinogenicity. A review. Environment International 53: 29-40.

BROCATO J et al. 2015. A Potential New Mechanism of Arsenic Carcinogenesis: Depletion of Stem-Loop Binding Protein and Increase in Polyadenylated Canonical Histone H3. 1 mRNA. Biologial Trace Elemement Research 166: 72-81.

BUNDSCHUH J et al. 2008. IBEROARSEN: Distribución de arsénico en las Regiones Ibérica e lberoamericana. Buenos Aires: CYTED. 230p.

BUNDSCHUH M et al. 2012. 'One century of arsenic exposure in Latin America: a review of history and occurrence from 14 countries', Science of The Total Environment 429: 2-35.

CARBONELL-BARRACHINA AA et al. 1998. Response of bean micronutrient nutrition to arsenic and salinity. Journal of Plant Nutricion 21: 1287-1299.

CARRASCO JA et al. 2005. Isolation and characterization of symbiotically effective Rhizobium resistant to arsenic and heavy metals after the toxic spill at the Aznalcóllar pyrite mine. Soil Biology and Biochemistry 37: 1131-1140.

CHAMORRO D et al. 2016. Reproductive output, seed anatomy and germination under water stress in the seeder Cistus ladanifer subjected to experimental drought. Environmental and Experimental Botany 123: $59-67$. 
CHEN BD et al. 2007. The arbuscular mycorrhizal fungus Glomus mosseae gives a contradictory effect on phosphorous and arsenic acquisition by Medicago sativa Linn. Science of The Total Environment 379: 226-234.

CHEN LR et al. 2016. Recent development in arsenic speciation and toxicity reduction of inorganic arsenic in food. European Journal of BioMedical Research 2: 27-31.

CHRISTOPHERSEN HM et al. 2012. Unraveling the influence of arbuscular mycorrhizal colonization on arsenic tolerance in Medicago: Glomus mosseae is more effective than G. intraradices, associated with lower expression of root epidermal Pi transporter genes. Frontiers in physiology 3: 91.

COHEN SM et al. 2013. Evaluation of the carcinogenicity of inorganic arsenic. Critical Reviews in Toxicology 43: 711-752.

DONG Y et al. 2008. Arbuscular mycorrhiza enhanced arsenic resistance of both white clover (Trifolium repens Linn.) and ryegrass (Lolium perenne L.) plants in an arsenic-contaminated soil. Environmental Pollution 1585: 174-181.

GREENE JC et al. 1988. Protocols for short term toxicity screening of hazardous waste sites. EPA 600/3. Washington: Environmental Protection Agency.

ESTEBAN E et al. 2003. High-affinity phosphate/arsenate transport in white lupin (Lupinus albus) is relatively insensitive to phosphate status. New Phytologist 158: 165-173.

FARIAS SS et al. 2003. Natural contamination with arsenic and other trace elements in ground waters of Argentine Pampean Plain. Science of The Total Environment 309: 187-199.

FARNESE FS et al. 2014. Effects of adding nitroprusside on arsenic stressed response of Pistia stratiotes L. under hydroponic conditions. International Journal Phytoremediaion 16: 123-137.

FU $\mathrm{Y}$ et al. 2011. Occurrence of arsenic in brown rice and its relationship to soil properties from Hainan Island, China. Environmental Pollution 159: 1757-1762.

HAMILTON MA et al. 1977. Trimmed Spearman-Karber Method for estimating median lethal concentrations in toxicity bioassays. Environmental Science and Technology 11: 714-719.

HARTLEY W \& LEPP NW 2008. Effect of in situ soil amendments on arsenic uptake in successive harvests of ryegrass (Lolium perenne cv Elka) grown in amended As-polluted soils. Environmental Pollution 156: 1030-1040.

HUANG TL et al. 2012. Transcriptomic changes and signalling pathways induced by arsenic stress in rice roots. Plant Molecular Biology 80: 587-608.

IBRAHIM EA. 2016. Seed priming to alleviate salinity stress in germinating seeds. Journal of Plant Physiology 192: 38-46.

IRIEL et al. 2015. Effect of arsenic on reflectance spectra and chlorophyll fluorescence of aquatic plants. Chemosphere 119: 697-703.

ISLAM E et al. 2015. Biochemical mechanisms of signaling: Perspectives in plants under arsenic stress. Ecotoxicology and Environmental Safety 114: 126-133.

KHAN MS et al. 2009. Role of plant growth promoting rhizobacteria in the remediation of metal contaminated soils Environmental Chemestry Letters 7: 1-19.

LA FUENTE $A$ et al. 2010. Reduced nodulation in alfalfa induced by arsenic correlates with altered expression of early nodulins. Journal of Plant Physiology 167: 286-291.

LARA-NUÑEZ A et al. 2015. Phytotoxicity of Sicyos deppei during tomato germination and its effects on the role of ABA and cell wall enzymes. Botanical Sciences 93(4): 771-781.

LI CX et al. 2007. Effects of arsenic on seed germination and physiological activities of wheat seedlings. Journal of Environmental Science 19: 725-732.

LI N et al. 2016. Arsenic uptake and translocation in plants. Plant and Cell Physiology 57: 4-13.

LI W et al. 2005. Effects of heavy metals on seed germination and early seedling growth of Arabidopsis thaliana. Plant Growth Regulation 46: 45-50.

LIU $Q$ et al. 2008. Effect of As on As uptake, speciation and nutrient uptake by winter wheat (Triticum aestivum L.) under hydroponic conditions. Journal of Environmental Sciences 20: 326-331.

LOMAX C et al. 2012. Methylated arsenic species in plants originate from soil microorganisms. The New Phytologist 193: 665-672.

LUAN ZQ et al. 2008. Individual and combined phytotoxic effects of cadmium, lead and arsenic on soy bean in Phaeozem. Plant Soil and Environment 54: 403-411.

MA JF et al. 2008. Transporters of arsenite in rice and their role in arsenic accumulation in rice grain. Proceedings of the National Academy of Sciences of the United States of America 105: 9931-9935.

MA LQ. 2001. A fern that hyperaccumulates arsenic. Nature 411: 579.

MA QF et al. 2009. Effects of arsenic on seed germination and seedling growth in three green manure seeds. Guangxi Agricultural Sciences 40: 1577-1581.

MACUR RE et al. 2001. Microbial populations associated with the reduction on enhanced mobilization of arsenic in mine tailings. Environmental Science Technology 35: 3676-3682.

MARQUEZ AP et al. 2007. Effect of arsenic, lead and zinc on seed germination and plant growth in black nightshade (Solanum nigrum L.) vs. clover (Trifolium incarnatum L.). Fresenius Environmental Bulletin 16: 896-903.

MARQUEZ-GARCIA R et al. 2012. Arsenic speciation in soils and Erica andevalensis Cabezudo \& Rivera and Erica australis L. from São Domingos Mine area, Portugal. Journal of Geochemical Exploration 119-120: 51-59. 
MASCHER R et al. 2002. Arsenate toxicity: effects on oxidative stress response molecules and enzymes in red clover plants. Plant Science 163: 961-969.

MITEVA E. 2002. Accumulation and effect of arsenic on tomatoes. Journal of Communications in Soil Science and Plant Analysis 33: 1917-1926.

NICOLLI HB et al. 1989. Groundwater contamination with arsenic and other trace elements in an area of the Pampa, Province of Córdoba, Argentina. Environmental Geology and Water Sciences 14: 3-16.

PAJUELO E et al. 2008. Toxic effects of arsenic on Sinorhizobium - Medicago sativa symbiotic interaction. Environmental Pollution 154: 203-211.

PÉREZ-CARRERA AL \& FERNÁNDEZ-CIRELLI A. 2013. Niveles de arsénico y vanadio en aguas naturales en el Departamento de Unión, sudeste de la provincia de Córdoba, Argentina. Augm Domus 5: 19-28

PÉREZ-CARRERA AL \& FERNÁNDEZ-CIRELLI A. 2014. Arsenic biotransference to alfalfa (Medicago sativa). International Journal of Environment and Health 7: 31-40.

RAHMAN MA \& HASEGAWA H. 2011. Aquatic arsenic: phytoremediation using floating macrophytes. Chemosphere 83: 633-646.

RAl A et al. 2011. Arsenic tolerances in rice (Oryza sativa) have a predominant role in transcriptional regulation of a set of genes including sulphur assimilation pathway and antioxidant system. Chemosphere 82: 986-995.

SEREGIN IV \& KOZHEVNIKOVA AD. 2005. Distribution of Cadmium, Lead, Nickel, and Strontium in Imbibing Maize Caryopsis. Russian Journal of Plant Physiology 52: 565-569.

SHAIBUR MRK et al. 2008. Critical toxicity of arsenic and elemental composition of arsenic induced chlorosis in hydroponic Sorghum. Water Air Soil Pollution 191: 279-292.

SHRI M et al. 2009. Effect of arsenic on growth, oxidative stress, and antioxidant system in rice seedlings. Ecotoxicology and Environmental Safety 72: 1102-1110.

SMEDLEY PL \& KINNIBURGH DG. 2002. A review of the source, behaviour and distribution of arsenic in natural waters. Applied Geochemistry 17: 517-568.

SMITH SE et al. 2010. Arsenic uptake and toxicity in plants: integrating mycorrhizal influences. Plant and Soil 327: 1-21.

SRIVASTAVA M et al. 2005. Antioxidant responses of hyperaccumulator and sensitive fern species to arsenic. Journal of Experimental Botany 56: 1335-1342.

TALUKDAR D. 2011. Effect of arsenic-induced toxicity on morphological traits of Trigonella foenum-graecum L. and Lathyrus sativus L. during germination and early seedling growth. Current Research Journal of Biological Sciences 3 : 116-123.

UPADHYAYA H et al. 2014. Arsenic Induced Changes in Growth and Physiological Responses in Vigna radiata Seedling: Effect of Curcumin Interaction. American Journal of Plant 5: 3609-3618.

USEPA. 1999. United States Environmental Protection Agency. Trimmed Spearman-Karber estimation of LC50 Values Users' Manual. Athens: Ecosystems Research Division.

VAZQUEZ ALDANA BR et al. 2013. Germination response of endophytic Festuca rubra seeds in the presence of arsenic. Grass and Forage Science 69: 462-469.

WAALKES MP et al. 2004. Mechanisms underlying arsenic carcinogenesis: hypersensitivity of mice exposed to inorganic arsenic during gestation. Toxicology 198: 31-38.

XU XY et al. 2008. Growing rice aerobically markedly decreases arsenic accumulation. Environmental Science Technology 42: 5574-5579.

YOON Y et al. 2015. Phytotoxicity of arsenic compounds on crop plant seedlings. Environmental Science and Pollution Research International 22: 11047-11056.

ZAR JH et al. 1996. Biostatistical analysis, Third ed., Prentice Hall, Inc. New Jersey.

ZHANG W et al. 2015. Biotransformation and detoxification of inorganic arsenic in Bombay oyster Saccostrea cucullata. Aquatic Toxicology 158: 33-40.

ZHAO FJ et al. 2009. Arsenic uptake and metabolism in plants. The New Pythologist 181: 777-794.

ZHAO FJ et al. 2010. Arsenic as a food chain contaminant: mechanisms of plant uptake and metabolism and mitigation strategies. Annual Review of Plant Biology 61: 535-559.

ZHU YG et al. 2014. Earth Abides Arsenic Biotransformations. Annual Review of Earth and Planetary Sciences 42: 443467. 